IOSR Journal of Pharmacy

e-ISSN: 2250-3013, p-ISSN: 2319-4219, www.iosrphr.org

Vol. 2, Issue 6, Nov-Dec. 2012 PP. 01-07

\title{
Pharmacological Studies on Ethanol Extract of Tragia Plukenetii R.Smith
}

\author{
M. Kalaivanan ${ }^{1} \&$ L. Louis Jesudass ${ }^{2}$ \\ ${ }^{1}$ Lecturer PG and Research Department of Pharmacology, Govt. Siddha Medical College, \\ Palayamkottai-627002. \\ ${ }^{2}$ Head of the Dept. of Botany, St. Xavier's College (Autonomous), Palayamkottai-627002.
}

\begin{abstract}
Tragia plukenetii R.Smith, is locally known as karunkanchori .It is widely used as traditional medicine for curing various therapeutic ailments. Present studies were conducted on rodents of either sex by administering ethanol dry extract to evaluate antipyretic, antiasthmatics, antispasmodic, diuretic, and analgesic properties against their respective standard drugs like Paracetamol, Chlorpheniramine Maleate, Piroxicam and Frusemide, to compare its significant activities and prove its scientific evidence to support the traditional claim and its effective uses for different diseases. The pharmacological investigations of the extract was exhibited a significant antipyretic, diuretic, analgesic activities.
\end{abstract}

Keywords - Tragia plukenetii, Paracetamol, Piroxicam, antipyretic, antiasthmatic, diuretic, and analgesic.

\section{INTRODUCTION}

Tragia plukenetii R.Smith (Euphorbiaceae) is an erect or climbing shrub distributed widely in India. The plant is traditionally used for the treatment of sore tongue and it also has diaphoretic action. The leaves are palmately 3-partite, lobes toothed or pinnatifid. The flowers are unisexual hairy racemes, capsule 3-lobed with seeds globose and smooth. [1]

The aim of this work is to document the medicinal uses of Tragia plukenetii R.Smith (Euphorbiaceae) and to evaluate pharmacological characteristics. This study was undertaken to evaluate the pharmacological actions of the extract and to provide a significant evidence to support the traditional claim and its therapeutic uses.

Plant collection

\section{MATERIAL AND METHODS}

T. plukenetii A.R.Smith (Euphorbiaceae) was collected in and around Tirunelveli District, Tamilnadu. Plant material was authenticated by the Survey of Medicinal Plants Unit- Siddha, Govt Siddha Medical College Campus, and Palayamkottai. A voucher of the specimen (No: 6298) was deposited at the herbarium unit at Survey of Medicinal Plants Unit- Siddha, Government Siddha Medical College Campus, and Palayamkottai for future verification.

\section{Preparation of Drug}

The plant material was shade dried and pulverized. Ethanol extract of the coarsely powdered material was prepared by employing Soxhlet method.The extract was concentrated and stored in brown bottles for future use.

Animals

Wister adult albino rats (100-150g), Guinea Pig (600-700g) and Rabbit (1-1.5kg) were procured from lab animal house, Dept of Pharmacology, Govt Siddha Medical College, Palayamkottai. The animals were housed in microlan boxes in a controlled environment (temperature $25^{\circ} \mathrm{C}$ and $12 \mathrm{hrs}$ dark and light cycle) with standard diet and water ad libitum.

\section{Methods}

Antipyretic activity (Brewer's yeast induced hyperpyrexia method.[2]

Animals of either sex (100-150g) were divided into three groups each consisting of six animals. The normal body temperature of each rat was measured rectally at one hour interval on a thermometer and recorded. Before yeast injection, the basal rectal temperatures of rats were recorded. After recording animals were given subcutaneous injection of $10 \mathrm{ml} / \mathrm{kg}$ body weight of $15 \% \mathrm{w} / \mathrm{v}$ yeast suspended in $0.5 \% \mathrm{w} / \mathrm{v}$ methyl cellulose 
solution for elevation of body temperature of rats. At the end of $18 \mathrm{hr}$ after yeast injection, the vehicle, the standard drug and the test drug were administered into different groups. Normal saline at a dose of $5 \mathrm{ml} / \mathrm{kg}$ bw was administered orally to the control groups of animals. Paracetamol at a dose of $150 \mathrm{mg} / \mathrm{kg}$ bw was administered orally at a dose to standard group of animals. To the test group alcoholic extract at a dose of 100 $\mathrm{mg} / \mathrm{kg}$ bw (body weight) was administered orally. Rectal temperature was recorded by clinical thermometer at regular interval of $0,1,2$, and $3 \mathrm{hrs}$ after drug administration and results are tabulated in Table-1.[3]

\section{Diuretic activity}

Diuretic activity of the drug and Frusemide was carried out by using in-vivo Lipschitz test method. [4] The rats were divided into three groups of six animals each and deprived of food and water for $18 \mathrm{hrs}$. All the rats have been received priming dose of normal saline $(25 \mathrm{ml} / \mathrm{kgbw})$ orally. The Extracts and Frusemide (standard) were dissolved in a normal saline. Group I served as control in which only normal saline $(25 \mathrm{ml}$ /kgbw) was administered through orally. Group II served as standard received frusemide (100mg/kgbw) and Group III served as treated received $(100 \mathrm{mg} / \mathrm{kgbw})$ of extracts intra peritoneal respectively. Immediately after administration, the rats (one in each cage) were placed in metabolic cages specially designed to separate urine and faeces. The urine was collected in a measuring cylinder up to 6hrs. During this period no food or water was made available to animals. The volume of urine collected was measured for all groups. The parameters taken for each individual rat were body weight before and after test period. Urine volume (concentrated for water intake during test period), concentration of $\mathrm{Na}+$ and $\mathrm{K}+$ in urine have been calculated and also recorded in Table- 2 .

\section{Antiasthma tic studies}

\section{Isolation of Guinea pig ileum preparation (in-vitro)}

Overnight fasted Guinea pig was sacrificed and ileum was mounted in an organ bath containing tyrode solution. The tyrode solution was continuously aerated and maintained at $37^{\circ} \mathrm{C}$. The tissue was allowed to equilibrate for $30 \mathrm{~min}$ under a load of $500 \mathrm{mg}$ of plasticine. The response of histamine was recorded by $5 \mathrm{~min}$ time cycle after contact 30 seconds. After obtaining a dose response curve of histamine $(10 \mu \mathrm{g} / \mathrm{ml}) \mathrm{on}$ ileum, ethanolic extract $(100 \mu \mathrm{g} / \mathrm{ml})$ was added to the presence of plant extract. This procedure was repeated for standard drug (CPM 10 $\mu \mathrm{g} / \mathrm{ml})$ as ethanolic extract. A dose response was based on maximum contractile response of histamine, in absence and presence of plant extract. The standard drug was recorded and tabulated (Table-3).

\section{Histamine induced bronchoconstruction in guinea pig. [5]}

Overnight fasted guinea pigs were divided into three groups each containing six animals. Group I was treated as control, Group II received standard drug Chlorpheniramine maleate (CPM 2mg/kgbw). Animals belonging to Group III received extract in a dose of $(100 \mathrm{mg} / \mathrm{kgbw})$. All the doses were given orally. Prior to drug treatment each animal was placed in the histamine chamber and exposed to $0.2 \%$ histamine aerosol. The Pre Convulsion Time (PCT) was determined from the time of to onset of convulsions. As soon as the PCT were noted, the animal were removed from the chamber and placed in air. $24 \mathrm{hr}$ later, the animals of group II and group III were again subjected to histamine aerosol after $1 \mathrm{hr}$ of drug administration and PCT was determined. The protection offered by treatment was calculated by using the following formula (Table-4).

$$
\% \text { protection }=(1-\mathrm{T} 1 / \mathrm{T} 2) \times 100
$$

Where, $\mathrm{T} 1=$ the mean of PCT before administration of test drug.

$\mathrm{T} 2=$ the mean of PCT after administration of test drug.

\section{Antispasmodic studies on isolated Rabbit jejunum:}

The method described by Schlemper [6] and modified by Amos [7] was adopted. Four adult rabbits which had free access to food and water were starved overnight prior to the experiment. The animals were sacrificed by blow on their head, exsanguinated and their abdomen cut open. Segments of their jejunum about $3.0 \mathrm{~cm}$ long were placed separately in $25 \mathrm{ml}$ organ bath containing Tyrode's solution, well aerated and maintained at $37^{\circ} \mathrm{c}$. The tissue was equilibrated for $60 \mathrm{mins}$ before use. Dose response curve for acetylcholine $(0.02-0.6 \mu \mathrm{g} / \mathrm{ml})$ were obtained. The contractile responses of the spasmogen were recorded on the smoked kymograph paper by means of a frontal writing lever. The tissue was washed three times with the physiological solution and allowed to rest before the addition of the spasmogen. The direct effect of the extract at a concentration of $(0.4-3.2 \mathrm{mg} / \mathrm{ml})$ was investigated on a sub maximal dose of acetylcholine $(0.4 \mu \mathrm{g} / \mathrm{ml})$ so as to study the effect of the extract on these spasmogens. The percentage inhibition of concentration induced by each dose of the extract against the specific spasmogen was calculated and tabulated (Table - 5). 
Analgesic studies

Analgesic activity of alcoholic extract evaluated by acetic-acid induced writhing response.[8]

Adult wistar albino rats (100-150gms) were divided into three groups of six rats each. The first group was given $10 \mathrm{ml} / \mathrm{kg}$ bw of normal saline I/P(Intra Peritoneal) and served as control, group II was given Piroxicam 10mg / kgbw I/P and served as standard. Group III was received $100 \mathrm{mg} / \mathrm{kgbw}$ of the extract given orally. Thirty minutes later, rats in all groups were treated with acetic acid $(0.06 \%$ of $1 \mathrm{ml} / 100 \mathrm{gm} \mathrm{I} / \mathrm{P})$. Five minutes after Acetic acid injection rats were placed in individual cage and the number of abdominal contractions was counted for each rat for a period of 10min (Table-6). Percentage of inhibition of writhing was calculated using the following expression:-

Inhibition $(\%)=$

Mean number of writhing (control) - Mean number of writhing (test)

Mean number of writhing (control)

Analgesic activity of alcoholic extract was evaluated by using Eddys hot plate method. [9]

Adult wistar albino rats (100-150g) were divided into three groups of six rats each. The first group was given $10 \mathrm{ml} / \mathrm{kg}$ bw of normal saline IP and served as control, group II received 10mg of Piroxicam / kgbw IP and served as standard, group III received $100 \mathrm{mg} / \mathrm{kgbw}$ of extracts orally respectively and served as treated group. The Eddys hot plate was maintained between $55^{\circ} \mathrm{C}$. The animals were placed on the hot plate and the time taken for licking or jumping was recorded using stopwatch. The reaction was observed at $0,15,30,60$, \&120mins (Table-7).

\section{Antipyretic activity}

\section{RESULTS}

The effect of ethanolic extract of T.plukenetii on yeast induced pyrexia has been shown in Table- 1 . Treatment with extract at a dose of $100 \mathrm{mg} / \mathrm{kg}$ bw and Paracetamol at a dose of $150 \mathrm{mg} / \mathrm{kgbw}$ decreased body temperature of yeast induced rats. The results obtained from both standards and extract treated groups were compared with the control group. A significant reduction in the yeast elevated rectal temperature was observed in the test group.

\section{Diuretic activity}

The results of diuretic activity of the extract obtained from the urine sample of rats are shown in Table 2. The ethanolic extract increased urine volume significantly $(\mathrm{p}<0.05)$ at $100 \mathrm{mg} / \mathrm{kgbw}$. The excretion of sodium and potassium ions is significantly increased $(\mathrm{p}<0.001)$.

\section{Antiasthmatic studies}

Ethanolic extract of T.plukenetii exhibited significant $(\mathrm{p}<0.001)$ percent decreased contraction at $100 \mu \mathrm{g} / \mathrm{ml}$ in isolated guinea pig ileum preparation (Table 3 ).

Table .4 showed the results of extract of T.plukenetii significantly protected the guinea pig against histamine induced bronchospasm. The guinea pigs exposed to histamine aerosol showed signs of progressive dyspnoea leading to convulsion. The extract significantly prolonged the latent period of convulsions as compared to control following the exposure of histamine aerosol. The action started after one hour of drug administration. The antihistaminic drug chlorpheniramine maleate used in the study produced significant increase in the latent period of convulsion after one hour. The results of present study indicate the utility of extract in antihistaminic study.

\section{Antispasmodic activity}

The extract of T.plukenetii inhibited acetylcholine induced contraction significantly $(\mathrm{p}<0.05)$ induced contraction of the rabbit jejunum as shown in Table 5. The median inhibitory concentration of the extract on these spasmogen was estimated to be $0.8 \mathrm{mg} / \mathrm{ml}$ on acetylcholine with the rabbit jejunum.

\section{Analgesic results}

In the present study the extract of T.plukenetii inhibited the acetic acid induced writhings $(\mathrm{p}<0.05)$ significantly (Table 6). They also showed significant reduction of licking response in Eddys hot plate method $(\mathrm{p}<0.05)$. (Table 7) 


\section{DISCUSSION}

The ethonolic extract of T.plukenetii possessed a significant antipyretic effect in yeast induced elevation of body temperature in experimental rats. It was revealed that the extract exhibited significant antipyretic activity at a dose of $100 \mathrm{mg} / \mathrm{kg}$ from, these sufficient periods of time.

On the basis of the results of the present investigation, we conclude that the extract produced a significant diuretic action. The diuretic activity of the plant may be due to the presence of phenol compounds.[10] Therefore, the whole part of the plant possesses diuretic activity is justified.

The morbidity and mortality of the asthma disease is increasing and making it is a global concern.[11] The syndrome of bronchial asthma is characterized by wide spread narrowing of the bronchial tree due to contraction of the smooth muscle in response to multiple stimuli resulting in the release of chemical mediators such as histamine.[12] Guinea pig ileum was used for screening of antihistaminic activity. The stimulation of $\mathrm{H}_{1}$ receptors produced graded dose related contraction of isolated guinea pig ileum.[13] In the present study, T.plukenetii $(100 \mu \mathrm{g} / \mathrm{ml})$ significantly inhibited the histamine induced contraction of isolated guinea pig ileum preparation indicating its $\mathrm{H}_{1}$ receptor antagonistic activity and supports the antiasthmatic properties of the plants.

Histamine induced broncho construction is the traditional immunological model of antigen induced airway obstruction. Histamine when inhaled causes hypoxia and leads to convulsion in guinea pig and causes very strong smooth muscle contraction, profound hypotension, and capillary dilation in cardiovascular system. A prominent effect caused by histamine leads to severe broncho constriction in guinea pigs that causes asphyxia and death. Broncho dilators can delay the occurrence of these symptoms.[14] The results of the study was confirmed the bronchodilator properties of the plant, justifying its traditional claim in the treatment of asthma.

From the present antispasmodic activity, the extracts of T.plukenetii was more sensitive to acetylcholine induced contractions of rabbit jejunum, this is because of the phytochemical constituents like saponins have been shown to decrease the acetylcholine contractions[15] and tannins widely used as astringents in gastrointestinal tract reduces peristaltic movement and intestinal secretions.[16] The observed activity clearly justifies the use of the plants in relieving colic pain and other gastrointestinal troubles. The result of the studies suggests the whole plant of T.plukenetii could be used in the treatment of some gastrointestinal problems and supports the claim of classical texts.

\section{CONCLUSION}

The observed studies are suggested that the whole plant of T.plukenetii could be used in significant antipyretic activity, diuretic property, anti asthmatic property, antispasmodic activity and analgesic action.

Table. 1 - Antipyretic Studies of Ethanolic extract of Tragia Plukenetii

\begin{tabular}{|c|c|c|c|c|c|c|c|}
\hline \multirow[t]{2}{*}{ Group } & \multirow[t]{2}{*}{ Treatment } & \multirow[t]{2}{*}{ Dose } & \multirow{2}{*}{$\begin{array}{l}\text { Initial rectal } \\
\text { temperature } \\
\text { in } C^{\circ} \text { before } \\
\text { yeast } \\
\text { injection }\end{array}$} & \multicolumn{4}{|c|}{$\begin{array}{l}\text { Rectal temperature in } \mathrm{C}^{\circ} \text { after } 18 \mathrm{hrs} \text { of yeast } \\
\text { injection (Mean } \pm \mathrm{SEM} \text { ) }\end{array}$} \\
\hline & & & & Ohr & $1 \mathrm{hr}$ & $2 \mathrm{hr}$ & $3 \mathrm{hr}$ \\
\hline I & Saline & $5 \mathrm{ml} / \mathrm{kg}$ & $37.65 \pm 0.1$ & $40.92 \pm 0.1$ & $40.48 \pm 0.17$ & $39.21 \pm 0.14$ & $39.13 \pm 0.16$ \\
\hline II & Paracetamol & $150 \mathrm{mg} / \mathrm{kg}$ & $37.25 \pm 0.2$ & $40.43 \pm 0.19$ & $38.65 \pm 0.17$ & $38.46 \pm 0.09 *$ & $37.88 \pm 0.18 *$ \\
\hline III & $\begin{array}{l}\text { Tragia } \\
\text { plukenetii }\end{array}$ & $100 \mathrm{mg} / \mathrm{kg}$ & $37.32 \pm 0.3$ & $40.58 \pm 0.11$ & $39.23 \pm 0.12$ & $38.01 \pm 0.14 *$ & $37.93 \pm 0.16 *$ \\
\hline
\end{tabular}

$\mathrm{n}=6$ in each group

* indicates $\mathrm{p}<0.01$ compared to control 
Table. 2 - Effect of Ethanolic extract of Tragia plukenetii on Urine volume and $\mathrm{Na}^{+}$, $\mathrm{K}^{+}$concentration in rats.

\begin{tabular}{|c|c|c|c|c|c|c|}
\hline Group & Treatment & Dose & $\begin{array}{l}\text { Urine } \\
\text { volume(ml/kg) }\end{array}$ & $\begin{array}{l}\text { Concentration } \\
\text { ions }\end{array}$ & of excreted & $\begin{array}{l}\mathrm{Na}^{+} / \mathrm{K}^{+} \\
\text {Ratio }\end{array}$ \\
\hline & & & & $\mathrm{Na}^{+}(\mathrm{mEq} / \mathrm{l})$ & $\mathrm{K}^{+}(\mathrm{mEq} / \mathrm{L})$ & \\
\hline I & Saline & $25 \mathrm{ml} / \mathrm{kg}$ & $2.75 \pm 0.075$ & $62.43 \pm 0.043$ & $50.62 \pm 0.010$ & 1.234 \\
\hline II & Frusemide & $100 \mathrm{mg} / \mathrm{kg}$ & $13.65 \pm 0.086^{*}$ & $154.25 \pm 0.170$ & $135.51 \pm 0.052 *$ & $1.139^{* * *}$ \\
\hline III & $\begin{array}{l}\text { Tragia } \\
\text { plukenetii }\end{array}$ & $100 \mathrm{mg} / \mathrm{kg}$ & $9.43 \pm 0.033 *$ & $123.44 \pm 0.065$ & $138.50 \pm 0.028^{*}$ & $0.695 * *$ \\
\hline
\end{tabular}

Results are expressed as mean \pm standard error $n=6$ in each group.

* Significantly difference compared to control group at $\mathbf{p}<0.05$.

** Significant difference compared to control group at $\mathbf{p}<0.001$

Table. 3- Effect of Ethanolic extract of Tragia plukenetii on histamine induced contraction In isolated Guinea pig ileum

\begin{tabular}{|c|c|c|c|}
\hline Dose (ml) & 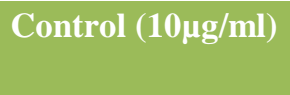 & $\begin{array}{l}\text { Tragia plukenetii } \\
(100 \mu \mathrm{g} / \mathrm{ml})\end{array}$ & $\begin{array}{l}\text { Chlorpheniramine } \\
\text { maleate }(10 \mu g / m l)\end{array}$ \\
\hline $\begin{array}{l}0.1 \\
0.2 \\
0.4 \\
0.8 \\
1.6 \\
3.2\end{array}$ & $\begin{array}{l}47.16 \pm 2.20 \\
65.41 \pm 3.02 \\
69.95 \pm 2.35 \\
81.41 \pm 2.73 \\
85.60 \pm 1.77 \\
100 \pm 1.75\end{array}$ & $\begin{array}{l}19.38 \pm 0.96 * * \\
33.15 \pm 1.67 * * \\
35.25 \pm 1.17 * * \\
39.18 \pm 1.41 * * \\
45.06 \pm 0.87 * * \\
50.33 \pm 0.93 * *\end{array}$ & $\begin{array}{l}19.12 \pm 1.37 * * \\
29.21 \pm 1.73 * * \\
41.70 \pm 2.77 * * \\
45.31 \pm 2.33 * * \\
54.20 \pm 1.97 * * \\
65.01 \pm 2.21 * *\end{array}$ \\
\hline \multicolumn{4}{|c|}{$\begin{array}{l}\mathbf{n}=5 \text {, values are Mean } \pm \mathrm{SEM} \\
\text { Control=DRC of histamine in absence of ethanolic extract of Tragia plukenetii, Tragia } \\
\text { plukenetii }(100 \mu \mathrm{g} / \mathrm{ml}) \\
\text { CPM }(10 \mu \mathrm{g} / \mathrm{ml})=\mathrm{DRC} \text { of histamine in presence of Chlorpheniramine maleate which is } \\
\text { standard }(10 \mu \mathrm{g} / \mathrm{ml}) \text {. } \\
\mathbf{p}<0.05, * * \mathbf{p}<0.01 \text {, and } * * * \mathbf{p}<0.001 \text { significantly different from control. }\end{array}$} \\
\hline
\end{tabular}

Table. 4 - Effect of Ethanolic extract of Tragia plukenetii on histamine induced bronchoconstrictionin Guinea pig.

\begin{tabular}{|c|c|c|c|}
\hline S.No. & Group & $\begin{array}{l}\text { Onset of convulsion } \\
\text { secondary }\end{array}$ & $\%$ Protection \\
\hline 1 & Control & $91.45 \pm 0.0093$ & - \\
\hline 2 & Standard & $1028.0 \pm 4.553^{*}$ & 91.10 \\
\hline 3 & Tragia plukenetii & $495.10 \pm 0.253^{* *}$ & 81.50 \\
\hline
\end{tabular}

Values are expressed as mean $\pm \operatorname{SEM}(n=6)$

*p<0.001 when compared with control group,

$* * p<0.001$ when compared with standard group.

Table. 5 - Antispasmodic activity of Ethanolic extract of Tragia plukenetii on Acetylcholine Induced contraction in isolated Rabbit Jejunum.

$P$ values less than $0.05(\mathrm{p}<0.05)$ were considered to be statistically significant. 
Table .6 - Analgesic activity of Ethanolic extract of Tragia plukenetii in acetic acid Induced writhing method.

\begin{tabular}{|llll|}
\hline Group & Treatment $(\mathrm{mg} / \mathrm{kg})$ & No. of abdominal writhings & \% Inhibition \\
I & Saline & $21 \pm 3.8$ & 00.00 \\
II & Piroxicam 10 & $10.2 \pm 2.1$ & 45.00 \\
& $\begin{array}{l}\text { Tragia } \\
100\end{array}$ & 59.80 \\
& & & \\
\hline
\end{tabular}

The results were considered statistically significant if the p- value were 0.05 or less.

Table. 7 - Analgesic activity of Ethanolic extract of Tragia plukenetii In Eddy's hot plate method.

\begin{tabular}{|c|c|c|c|c|c|c|}
\hline \multirow[t]{2}{*}{ Group } & \multirow{2}{*}{$\begin{array}{l}\text { Treatment } \\
\text { (mg/kg) }\end{array}$} & \multicolumn{5}{|c|}{ Reaction time in minutes } \\
\hline & & 0 & 15 & 30 & 60 & 120 \\
\hline $\mathbf{I}$ & Saline & $5.1 \pm 0.21$ & $5.7 \pm 0.20$ & $5.6 \pm 0.24$ & $5.5 \pm 0.40$ & $5.4 \pm 0.23$ \\
\hline II & Piroxicam 10 & $5.6 \pm 0.21$ & $6.2 \pm 0.20$ & $6.8 \pm 0.30 *$ & $6.2 \pm 0.36 * *$ & $5.8 \pm 0.37 * *$ \\
\hline III & $\begin{array}{l}\text { Tragia } \\
\text { plukenetii } 100\end{array}$ & $5.6 \pm 0.31$ & $9.4 \pm 0.50$ & $8.1 \pm 0.30 *$ & $7.2 \pm 0.32 *$ & $6.8 \pm 0.30 *$ \\
\hline
\end{tabular}

\section{REFERENCES}

[1]. Yoganarasimhan, S.N. (2000). Medicinal plants of india Vol. 2, Tamil Nadu. Page No:552

[2]. Turner, R.A.1965. Screening method in Pharmacology, Academy Press, Newyork \&London.Page No: 268

[3]. Vogel H.G, (2002). Drug discovery and Evaluation Pharmacological Assays, $2^{\text {nd }}$ edition, Springer, Newyork, 716

[4]. Lipschitz W L, Haddian Z, and Kepscar A(1943). Bioassay of diuretics. J. Pharmacol. Exp Ther. 79: 110

[5]. Sheth, U.K., N.K. Dadkar and N.G. Kamat, (1972). Selected topics in experimental pharmacology. Kothari Book Depot, Bombay (India)

[6]. Schlemper, V.A. Ribas, M.N and Filho, V.C (1996). Antispasmodic effect of hydroalcoholic extract of Marrubium vulgare on isolated tissue. Phytomedicine, . $3: 211-216$

[7]. Amos, S., Gammaniel, K., Adamu, M., Bukar, B., Akah, P. and Wambebe, C. (2000). Pharmacological effects of aqueous extracts of Chrysanthellum indicum on gastrointestinal smooth muscles. Journal of Herbs, Spices and Medicinal plants. 7(3): 45-53

[8]. Seigmund, E., Cadmus, R. and Lu, G., (1957).A method for evaluating non- narcotic and narcotic analgesics. Proc. Soc. Exp. Biol. Med. 95: 729-733

[9]. Eddy, N.B. and Leimbach, D.J., (1953).Synthetic analgesics, II Dithienyl butenyl and di ethienylamines. J. Pharmacol. Exptl. Therap. 107: 385-393. 
[10]. Galati EM, Mondello MR, Giuffrida D, Dugo G, Miceli N, Pergolizzi, S. (2003).Chemical characterization and biological effects of Sicilian Opuntia\&Ficus indica(L)Mill. Fruit juice: antioxidant and anti ulcerogenic activity. J Agric and Food Chem; 51(17): 4903-4908

[11]. Byme P.O., (1999).The clinical expression of allergy in the lungs. Allergy 54:7-14

[12]. Abraham E, Deodhar M.M., and Natu M.V., (1992).A comparative study of the bronchodilator activity of the calcium channel antagonist on histamine induced bronchospasm in Guinea pigs. Indian $J$. Pharmacol. 24(4):

[13]. 231-232

[14]. Saraf M., Patwardhan B.K., (1998).Pharmacological studies on Sarcostemma brevistigma Wight. Part II:Bronchodilator activity. Indian drugs 26: 54-57

[15]. Nayampalli S.S., Desai N.K., and Ainapure S.S., (1986). Anti allergic properties of Tinospora cordifolia in animal models.Indian J. Pharmacol. 18(4). 250-252

[16]. Bouic P.J.D., (1999). Plant sterols and sterolins: A review of their immune modulating properties.Altern. Med. Rev. 4:170-177

[17]. 16. Ramstad, E. (1959) Pharmacognosy. Blakiston Division, Mcgrow - Hill Books Company Inc., London, Newyork, P. 28-50. 